\title{
Removal of Cyanide-Contaminated Water by Vetiver Grasses
}

\author{
Piyada Wachirawongsakorn ${ }^{1}$, Tongsai Jamnongkan ${ }^{2} \&$ Mohd Talib Latif ${ }^{3}$ \\ ${ }^{1}$ Faculty of Science and Technology, Pibulsongkarm Rajabhat University, Phitsanulok, Thailand \\ ${ }^{2}$ Faculty of Science at Siracha, Kasetsart University, Chonburi, Thailand \\ ${ }^{3}$ School of Environmental and Natural Resource Sciences, Faculty of Science and Technology, University \\ Kebangsaan Malaysia, Bangi, Selangor, Malaysia \\ Correspondence: Piyada Wachirawongsakorn, Faculty of Science and Technology, Pibulsongkarm Rajabhat \\ University, Phitsanulok, 65000, Thailand. Tel: 669-4536-6515. E-mail: piyada333@hotmail.com
}

Received: November 22, 2014

Accepted: August 28, 2015 Online Published: November 30, 2015

doi:10.5539/mas.v9n13p252

URL: http://dx.doi.org/10.5539/mas.v9n13p252

The research is financed by Pibulsongkarm Rajabhat University under the aid of National Research Council of Thailand.

\begin{abstract}
Vetiver grass and it usages have been widely investigated in many researches as the preferred plant species due to its known efficiency, low cost, the ease of availability and spread. This research aimed to use four different vetiver grass (Vetiveria zizanioides) ecotypes to remove cyanide $\left(\mathrm{CN}^{-}\right)$-contaminated water for improve its quality. Growth capability, tolerance and removal efficiency were evaluated. The results showed that the vetiver grass had a $100 \%$ survival rate for one month after planting. Songkhlar3 had the longest leaves, followed by Surat-Thani, Sri Lanka and Monto, respectively. Root lengths of all ecotypes showed no significant differences $(\mathrm{p} \leq 0.05)$. All vetiver grass ecotypes could potentially purify $\mathrm{CN}^{-}$-contaminated water at lower concentrations of $\leq 35 \mathrm{mg} \mathrm{CN} / \mathrm{L}$. The Monto ecotype had the highest $\mathrm{CN}^{-}$removal efficiency at all $\mathrm{CN}^{-}$concentration levels, showing $100 \% \mathrm{CN}^{-}$removal from the $5-45 \mathrm{mg} \mathrm{CN}^{-} / \mathrm{L}$ contaminated water samples within $2-5$ weeks growth. The tolerance of vetiver grass to $\mathrm{CN}^{-}$was a more important factor than growth rate when selecting a vetiver grass ecotype for $\mathrm{CN}^{-}$phytoremediation.
\end{abstract}

Keywords: vetiver grass, phytoremediation, cyanide, Songkhlar3, Sri Lanka, Surat-Thani, Monto

\section{Introduction}

Cyanide $\left(\mathrm{CN}^{-}\right)$is a radical combination of carbon and nitrogen, which can be found in a wide variety of life forms and has a large-scale presence in the environment. It is attributed to manufacturing sources and is used extensively in industry (Dash, Gaur \& Balomajumder, 2009). These industries utilize a combination of free $\mathrm{CN}^{-}$ and $\mathrm{CN}^{-}$complex-based compounds in various operations, including: the beneficiation of metals, electroplating, case hardening, automotive manufacturing, circuitry board manufacturing, and in chemical industries (Patil \& Paknikar, 2000). $\mathrm{CN}^{-}$is also used in mining to extract gold and silver from ores, particularly low-grade ores and ores that cannot be readily treated through simple physical processes such as crushing and gravity separation (Logsdon, Hagelstein \& Mudder, 1999). $\mathrm{CN}^{-}$is commonly found as a contaminant in wastewaters through release from the $\mathrm{CN}^{-}$leaching gold recovery (CLGR) process (Logsdon el al., 1999). This is a major factor contributing to the bulk of the occurrence of $\mathrm{CN}^{-}$in the environment. Most of the $\mathrm{CN}^{-}$used in industrial mining is handled without observable devastating environmental consequences, but in informal, small-scale mining, its use is poorly regulated and the waste treatment is insufficient (Elbel, Evangelou \& Schaeffer, 2007). The unwanted extraction is often stored in open tailing ponds of areas equal to 150 ha or larger (Eisler \& Wiemeyer, 2004). This waste contains up to $120 \mathrm{mg} / \mathrm{L}$ free $\mathrm{CN}^{-}$and $400 \mathrm{mg} / \mathrm{L}$ total $\mathrm{CN}^{-}$, including various $\mathrm{CN}^{-}$-heavy metal complexes (Elbel et al, 2007). The environmental risk of $\mathrm{CN}^{-}$-contaminated wastewater is not limited to the effluent but also includes the possibility of emitted hydrocyanic gas. Hydrocyanic gas is slightly soluble in water and readily dissociates into hydrogen and $\mathrm{CN}^{-}$at low $\mathrm{pH}$ in aqueous solutions (Santos, Ntwampe \& Doughari, 2013).

Many countries have been faced with the environmental problem of $\mathrm{CN}^{-}$-contaminated effluence from gold 
mining processes, such as when the dam of a gold leaching retention basin burst in north-western Romania, near the city of Baia Mare, where 100,000 $\mathrm{kg}$ of $\mathrm{CN}^{-}$were released to the river (UNEP/OCHA, 2000). In South America, small-scale mining, comprising many non-industrial mining activities that are not under public authority control, results in wastewater discharge into rivers without treatment (Elbel el al., 2007). Thailand is a country that has had a mining industry policy for more than 50 years. This is because successive Thai governments have believed that dependence on mineral resources and the mining industry will result in high economic growth (Watcharapon \& Suntaree, 2009). Mining companies in the Loei region of Thailand recently discovered large gold ore deposits and expect to be processing 440,000 tonnes of ore in the future. If this proves true, Thailand could be the country with the world's biggest gold reserves, surpassing the US, which holds over 8,000 tonnes. Currently ranked 25 th, Thailand sits on gold reserves of 152.4 tonnes, valued at $4 \%$ of foreign reserves, which stood slightly below US\$180 billion or about Bt5 trillion (The Nation, 2013). Consequently there is likely to be an increase in mining in Thailand and an associated increase in the environmental and health effects.

The National Health Commission office (2011) reported that blood sample testing of 440 villagers around the gold mine in Khaoluang Sub-District, Wang Saphung District, Loei Province, Thailand was carried out by the Loei Provincial Health Office and Wang Saphung Hospital. The samples were referred to Ramathibodi Hospital for $\mathrm{CN}^{-}$testing and to the Bureau of Occupational and Environmental Diseases, Department of Disease Control, Ministry of Public Health for heavy metal for (mercury and lead) testing. The test results showed that lead and especially mercury, were found in every sample and 38 were over the standard level. Also, $\mathrm{CN}^{-}$was found in 348 blood samples, with 84 people having it over the standard level. Only 103 samples are $\mathrm{CN}^{-}$free and lead was found in every sample. This was presumed to be caused by residues in drinking water and results in rashes and skin problems. Some domestic animals die without clear causes in this area.

Therefore, the control and remediation of $\mathrm{CN}^{-}$-contaminated water is required due to the potential hazards associated with $\mathrm{CN}^{-}$. The most common methods include the alkaline chlorination process, the sulfur dioxide air process which utilizes $\mathrm{SO} 2$ and air at an alkaline $\mathrm{pH}$ to oxidize the $\mathrm{CN}^{-}$, the copper-catalysed hydrogen peroxide process, the Caro's acid process, ion exchange, reverse osmosis, etc. (Akcil, Karahan \& Ciftci, 2003). Although these methods can be used in detoxifying free $\mathrm{CN}^{-}$bearing waste, they pose significant drawbacks, including the inability to treat $\mathrm{CN}^{-}$complexes, the high costs of reagents, equipment, maintenance and royalty payments and the generation of unfavourable by-products such as chlorinated compounds (Maegala, Fridelina \& Abdul, 2011). Although this range of chemical methods exists, biological methods are preferred for $\mathrm{CN}^{-}$removal because of their low operation costs, their ability to remove a wide range of $\mathrm{CN}^{-}$compounds, and their ability to produce high quality effluent (Botz, Mudder \& Akcil, 2005). Phytoremediation is an emerging green technology that uses plants to remediate water contaminated with toxic metals, organics, and radionuclides (Alkorta \& Garbisu, 2001) The plant actions can degrade, adsorb, accumulate and volatilize many different compounds and classes of compounds (Newman \& Reynolds, 2004). Various plants have been shown to tolerate cyanides and to eliminate cyanides from nutrient solutions (Elbel el al., 2007). The fact that plants can remove high amounts of cyanides might be applicable to the elimination of cyanides in waste and wastewater, e.g., from gold mining. This could be realized by constructing wetlands or artificial ponds with aquatic plants, if the concentration is low, or by areas of land planted with selected crops or trees and irrigated with wastewater containing cyanides (at higher concentrations) (Trapp, Larsen, Pirandello \& Danquah-Boakye, 2003).

There are many plant species which may be suitable for wastewater treatment ponds that have not yet been tested. Vetiver grass is a perennial grass belonging to the Poaceae family. It has short rhizomes and a massive, finely structured root system. Likewise, the vetiver grass is known for its enormous biomass production rate, high resistance to pests, diseases and fire (Dudai \& Putievsky, 2006) and for its heavy metal and nutrient absorption capacities (Andra et al., 2009). Many researchers have suggested the use of this plant for heavy metal soil decontamination (Roongtanakiat, 2009), removal of pollutants from landfill leachate (Xia, Liu \& Ao, 2000), wastewater treatment and mine tailings decontamination (Roongtanakiat, Tangruangkiat \& Meesat, 2007). These reasons, along with the high availability of vetiver grass in the local area, make it an appropriate candidate for $\mathrm{CN}^{-}$decontamination. Therefore, this study aims to determine the $\mathrm{CN}^{-}$tolerance and elimination capacity of different vetiver grass ecotypes in $\mathrm{CN}^{-}$-contaminated water.

\section{Method}

This research experiment was carried out to investigate the ability of vetiver grass (Vetiveria zizanioides) to uptake $\mathrm{CN}^{-}$-contaminated water. Four different vetiver grass ecotypes including Songkhlar3, Sri Lanka, Surat-Thani and Monto were hydroponically planted in artificially contaminated cyanide water samples with concentrations of $5,10,15,20,25,30,35,40,45$ and $50 \mathrm{mg} \mathrm{CN}^{-} / \mathrm{L}$ and left to grow for two months. Growth 
capability, toxic tolerance and removal efficiency were investigated.

\subsection{CN Solutions}

The $\mathrm{CN}^{-}$solutions with concentrations of $5,10,15,20,25,30,35,40,45$ and $50 \mathrm{mg} \mathrm{CN} / \mathrm{L}$ were prepared in the laboratory by dissolving $47.1,94.3,141.4,188.5,235.63,282.8,329.9,377.0,424.1$ and $471.3 \mathrm{mg} \mathrm{NaCN}$ in $5 \mathrm{~L}$ distilled water, respectively. The $\mathrm{pH}$ of the solution was adjusted to about 12.0 with sodium hydroxide because $\mathrm{CN}^{-}$becomes volatile at $\mathrm{pH}$ values lower than 11.5 (Elbel el al., 2007).

\subsection{Vetiver Grass}

Vetiver grass is normally a dense, clumping perennial grass. It requires a hot and humid climate. It is adaptable to a wide range of soil and climatic conditions. It can Tolerance to extreme climatic variation such as prolonged drought, flood, submergence and extreme temperature from $-14^{\circ} \mathrm{C}$ to $+55^{\circ} \mathrm{C}$, ability to re-grow very quickly after being affected by drought, frosts, salinity and adverse conditions after the weather improves or soil ameliorants added. It can be tolerance to wide range of soil $\mathrm{pH}$ from 3.3 to 12.5 without soil amendment, highly tolerant to growing medium high in acidity, alkalinity, salinity, sodicity and magnesium (Truong, Van \& Pinners, 2015).

This experiment use vetiver grass for water treatment. Four vetiver grass (Vetiveria zizanioides) ecotypes including Songkhlar3, Sri Lanka, Surat-Thani and Monto, were used for the experiments. The age of vetiver grass was between 1.5-2 months and they were pretreated in water with organic fertilizer (Por-Dor 2) for a week. They were cut to $20 \mathrm{~cm}$ leaf height and $5 \mathrm{~cm}$ root length prior to the experiments and were arranged with one plant per sample of $5 \mathrm{~L}$ contaminated water.

\subsection{Experimental Design}

All four vetiver grass ecotypes were planted in $5 \mathrm{~L}$ sample pots containing $5,10,15,20,25,30,35,40$, 45 and $50 \mathrm{mg} \mathrm{CN}^{-} / \mathrm{L}$. The layout plan was a completely randomized design with three replications for each ecotype at each concentration. Control experiments were established without $\mathrm{CN}^{-}$and experiments were carried out in triplicate; experimental errors were estimated and depicted with error bars. After 7, 14, 21, 28, 35, 42,49 and 56 days, the length of leaves and roots were measured. The remaining $\mathrm{CN}^{-}$concentrations in the pots were analysed. The ecotypes that had the highest $\mathrm{CN}^{-}$removal efficiency were recommended for $\mathrm{CN}^{-}$phytoremediation.

\subsection{Chemical Analysis}

The remaining $\mathrm{CN}^{-}$concentrations in the water samples for $\mathrm{CN}^{-}$removal tests were analysed using the $\mathrm{CN}$-ion selective electrode (ELIT 8291 crystal membrane) method following the METHOD 4500-CN.

\subsection{Statistical Analysis}

All data was analysed using SPSS for Windows version 17.0. A one-way ANOVA test (95\% confidence interval) was used to evaluate differences between groups and $p \leq 0.05$ was considered statistically significant.

\section{Results}

\subsection{Growth Capability of Vetiver Grass}

The results revealed that all vetiver grass ecotypes could grow in $\mathrm{CN}^{-}$-contaminated water. Most of the vetiver grass plants showed rapid growth in the first three weeks and then slower growth during the later weeks. The average leaf and root lengths of the four vetiver grass ecotypes at the end of experiment are shown in Table 1. The statistical results of growth capability, at a significance level of 0.05 , revealed that Songkhlar3 had the longest leaf length at most of the different $\mathrm{CN}^{-}$concentration levels. Leaf and root growth comparisons under different levels of $\mathrm{CN}^{-}$contamination found that average leaf and root lengths were shorter at the higher $\mathrm{CN}^{-}$ concentration levels in every ecotype and significantly shorter than both controls. The $\mathrm{CN}^{-}$concentration played an important role in vetiver grass growth as found in other research relating to heavy metal removal by vetiver grass (Gupta, Roy \& Mahindrakar, 2012) and $\mathrm{CN}^{-}$phytoremediation by water hyacinths (Elbel el al., 2007). According to Somwang, Yothasiri, Tubngearn, Panichnork \&Limarroon (2005) the height of the vetiver grass shoot was distinctively decreased at higher concentrations of heavy metal contamination in wastewater, due to the toxicity of heavy metals affecting the growth of the vetiver grass. Sheldon and Menzies (2005) found that heavy metals affected the leaf and root growth of vetiver grass and an experiment in Pang, Chan, Liang \& Wong (2003) indicated that high proportions of lead and zinc in tailings greatly inhibited the leaf growth, dry matter accumulation, and photosynthesis of leaves. Moreover, Roongtanakiat (2009) indicated that two factors affecting heavy metal uptake are the concentration of heavy metals in the plant and the plant biomass. However, leaf and root lengths of control 1 (distilled water) and control 2 (distilled water with $\mathrm{pH}$ 12) were also significantly different $(\mathrm{p} \leq 0.05)$. This indicated that the $\mathrm{pH} 12$ control solution caused a decrease in the growth of vetiver grass, which generally grows best in a $\mathrm{pH}$ range of 5.5-7.0 ( $\mathrm{Lu}, 2009)$. Optimal water $\mathrm{pH}$ for the growth of water 
hyacinth is neutral but it can tolerate $\mathrm{pH}$ values from 4 to 10 (El-Gendy, Biswas \& Bewtra, 2004), while vetiver grass tolerates wide range of $\mathrm{pH}$, salinity and sodicity (Dulton, Smith and Truong, 1996; Truong et al., 2003). pH is an factor to consider for wastewater treatment using vetiver grass; the optimal $\mathrm{pH}$ for vetiver grass from Australia was 9.5, while the others was 10.5 (Truong, Carlin, Cook \& Thomas, 2003).

Table 1. Leaf and root lengths of all vetiver grass ecotypes at the end of the experiment after exposure to different concentrations of $\mathrm{CN}^{-}$

\begin{tabular}{|c|c|c|c|c|c|c|c|c|}
\hline \multirow{2}{*}{$\begin{array}{c}\mathrm{CN}^{-} \\
(\mathrm{mg} / \mathrm{L})\end{array}$} & \multicolumn{4}{|c|}{ Leaf length $(\mathrm{cm})$} & \multicolumn{4}{|c|}{ Root length (cm) } \\
\hline & Sri Lanka & Songkhlar3 & Surat. & Monto & Sri Lanka & Songkhlar3 & Surat. & Monto \\
\hline 5 & $26.1 \pm 0.7 \mathrm{f}$ & $30.0 \pm 1.5 \mathrm{c}$ & $27.9 \pm 0.8 \mathrm{e}$ & $25.0 \pm 1.1 \mathrm{~g}$ & $11.0 \pm 0.4 \mathrm{c}$ & $10.2 \pm 1.3 \mathrm{c}$ & $11.0 \pm 1.3 \mathrm{c}$ & $10.2 \pm 1.1 \mathrm{~d}$ \\
\hline 10 & $24.1 \pm 1.5 \mathrm{~h}$ & $26.0 \pm 1.4 \mathrm{f}$ & $25.0 \pm 1.0 \mathrm{~g}$ & $24.0 \pm 1.3 \mathrm{~h}$ & $9.2 \pm 1.5 \mathrm{e}$ & $9.0 \pm 1.1 \mathrm{e}$ & $9.2 \pm 1.0 \mathrm{e}$ & $8.8 \pm 0.8 \mathrm{f}$ \\
\hline 15 & $24.4 \pm 0.4 \mathrm{~h}$ & $26.0 \pm 0.1 \mathrm{f}$ & $25.1 \pm 0.7 \mathrm{~g}$ & $23.9 \pm 1.0 \mathrm{i}$ & $9.1 \pm 1.5 \mathrm{e}$ & $9.1 \pm 1.9 \mathrm{e}$ & $9.0 \pm 0.8 \mathrm{e}$ & $8.8 \pm 0.9 \mathrm{f}$ \\
\hline 20 & $23.8 \pm 0.5 \mathrm{i}$ & $24.1 \pm 0.5 \mathrm{~h}$ & $23.8 \pm 1.5 \mathrm{i}$ & $23.7 \pm 1.5 \mathrm{i}$ & $8.2 \pm 1.5 \mathrm{f}$ & $8.2 \pm 1.0 \mathrm{f}$ & $8.2 \pm 0.5 \mathrm{f}$ & $8.0 \pm 1.2 \mathrm{f}$ \\
\hline 25 & $23.9 \pm 1.7 \mathrm{i}$ & $24.2 \pm 0.2 \mathrm{~h}$ & $23.4 \pm 1.0 \mathrm{i}$ & $23.2 \pm 1.0 \mathrm{i}$ & $8.5 \pm 1.3 \mathrm{f}$ & $8.8 \pm 1.3 \mathrm{f}$ & $8.4 \pm 2.6 \mathrm{f}$ & $8.2 \pm 0.9 \mathrm{f}$ \\
\hline 30 & $22.0 \pm 0.7 \mathrm{j}$ & $24.1 \pm 1.0 \mathrm{~h}$ & $22.3 \pm 0.5 \mathrm{j}$ & $22.0 \pm 0.1 \mathrm{j}$ & $8.3 \pm 1.5 \mathrm{f}$ & $8.1 \pm 1.0 \mathrm{f}$ & $8.1 \pm 0.5 f$ & $7.9 \pm 1.3 \mathrm{~g}$ \\
\hline 35 & $22.4 \pm 0.6 \mathrm{j}$ & $23.6 \pm 1.2 \mathrm{i}$ & $22.5 \pm 0.4 \mathrm{j}$ & $22.0 \pm 0.7 \mathrm{j}$ & $8.0 \pm 0.5 \mathrm{f}$ & $7.3 \pm 1.8 \mathrm{~g}$ & $7.4 \pm 2.0 \mathrm{~g}$ & $7.9 \pm 0.7 \mathrm{~g}$ \\
\hline 40 & $22.1 \pm 1.3 \mathrm{j}$ & $23.3 \pm 1.7 \mathrm{i}$ & $22.1 \pm 1.0 \mathrm{j}$ & $21.0 \pm 0.7 \mathrm{k}$ & $8.0 \pm 1.4 \mathrm{f}$ & $7.4 \pm 1.0 \mathrm{~g}$ & $7.3 \pm 1.5 \mathrm{~g}$ & $7.1 \pm 0.8 \mathrm{~g}$ \\
\hline 45 & $22.8 \pm 1.1 \mathrm{j}$ & $23.1 \pm 0.4 \mathrm{i}$ & $22.5 \pm 1.5 \mathrm{j}$ & $21.9 \pm 0.8 \mathrm{k}$ & $8.0 \pm 1.0 \mathrm{f}$ & $7.5 \pm 1.0 \mathrm{~g}$ & $7.3 \pm 2.0 \mathrm{~g}$ & $7.0 \pm 1.0 \mathrm{~g}$ \\
\hline 50 & $21.6 \pm 0.5 \mathrm{k}$ & $22.7 \pm 1.5 \mathrm{j}$ & $21.5 \pm 1.0 \mathrm{k}$ & $21.5 \pm 1.0 \mathrm{k}$ & $7.4 \pm 1.0 \mathrm{~g}$ & $7.2 \pm 1.0 \mathrm{~g}$ & $7.3 \pm 1.0 \mathrm{~g}$ & $7.0 \pm 0.8 \mathrm{~g}$ \\
\hline $\mathrm{C}-1^{๕}$ & $30.4 \pm 1.4 \mathrm{c}$ & $32.0 \pm 1.5 \mathrm{a}$ & $31.5 \pm 0.5 \mathrm{~b}$ & $29.8 \pm 0.8 \mathrm{~d}$ & $13.2 \pm 1.5 \mathrm{a}$ & $12.7 \pm 0.5 \mathrm{~b}$ & $12.4 \pm 1.0 \mathrm{~b}$ & $11.6 \pm 0.9 \mathrm{c}$ \\
\hline $\mathrm{C}-2^{* *}$ & $29.3 \pm 1.5 \mathrm{~d}$ & $31.4 \pm 2.5 b$ & $30.0 \pm 1.1 \mathrm{c}$ & $27.6 \pm 0.7 \mathrm{e}$ & $12.0 \pm 1.0 \mathrm{~b}$ & $12.2 \pm 0.5 \mathrm{~b}$ & $12.0 \pm 0.5 b$ & $10.1 \pm 0.3 \mathrm{~d}$ \\
\hline
\end{tabular}

Note. *Control-1 is distilled water; **Control-2 is distilled water with $\mathrm{pH} 12$; Mean and standard deviation $(n=3)$.

\subsection{Tolerance of Vetiver Grass}

The tolerance of all vetiver grass ecotypes to $\mathrm{CN}^{-}$was studied during the experiment by counting the number of weeks the plants survived. The Monto ecotype was significantly more tolerant than the other ecotypes at every $\mathrm{CN}^{-}$contamination level $(\mathrm{p} \leq 0.05)$, followed by Sri Lanka, Surat-Thani and Songkhlar3, respectively. The Monto ecotype survived for 6-8 weeks after treatment with $\mathrm{CN}^{-}$-contaminated water, while Sri Lanka, Surat-Thani and Songkhlar3 survived for 5-8, 4-8 and 4-6 weeks, respectively. At 5-15 $\mathrm{mg} \mathrm{CN}^{-} / \mathrm{L}$, the Monto and Sri Lanka ecotypes survived until the end of experiment, while the Surat-Thani and Songkhlar3 ecotypes only survived for 5-7 weeks. The experiment indicated that the tolerance of vetiver grass to $\mathrm{CN}^{-}$decreased at higher $\mathrm{CN}^{-}$concentration levels (Figure 1). 


\section{$\square 5 \mathrm{mg} / \mathrm{L} \quad \square 10 \mathrm{mg} / \mathrm{L}$ 日 $15 \mathrm{mg} / \mathrm{L} \square 20 \mathrm{mg} / \mathrm{L} \square 25 \mathrm{mg} / \mathrm{L}$} $\square 30 \mathrm{mg} / \mathrm{L} \square 35 \mathrm{mg} / \mathrm{L} \square 40 \mathrm{mg} / \mathrm{L} \square 45 \mathrm{mg} / \mathrm{L} \mathbf{\square} 50 \mathrm{mg} / \mathrm{L}$

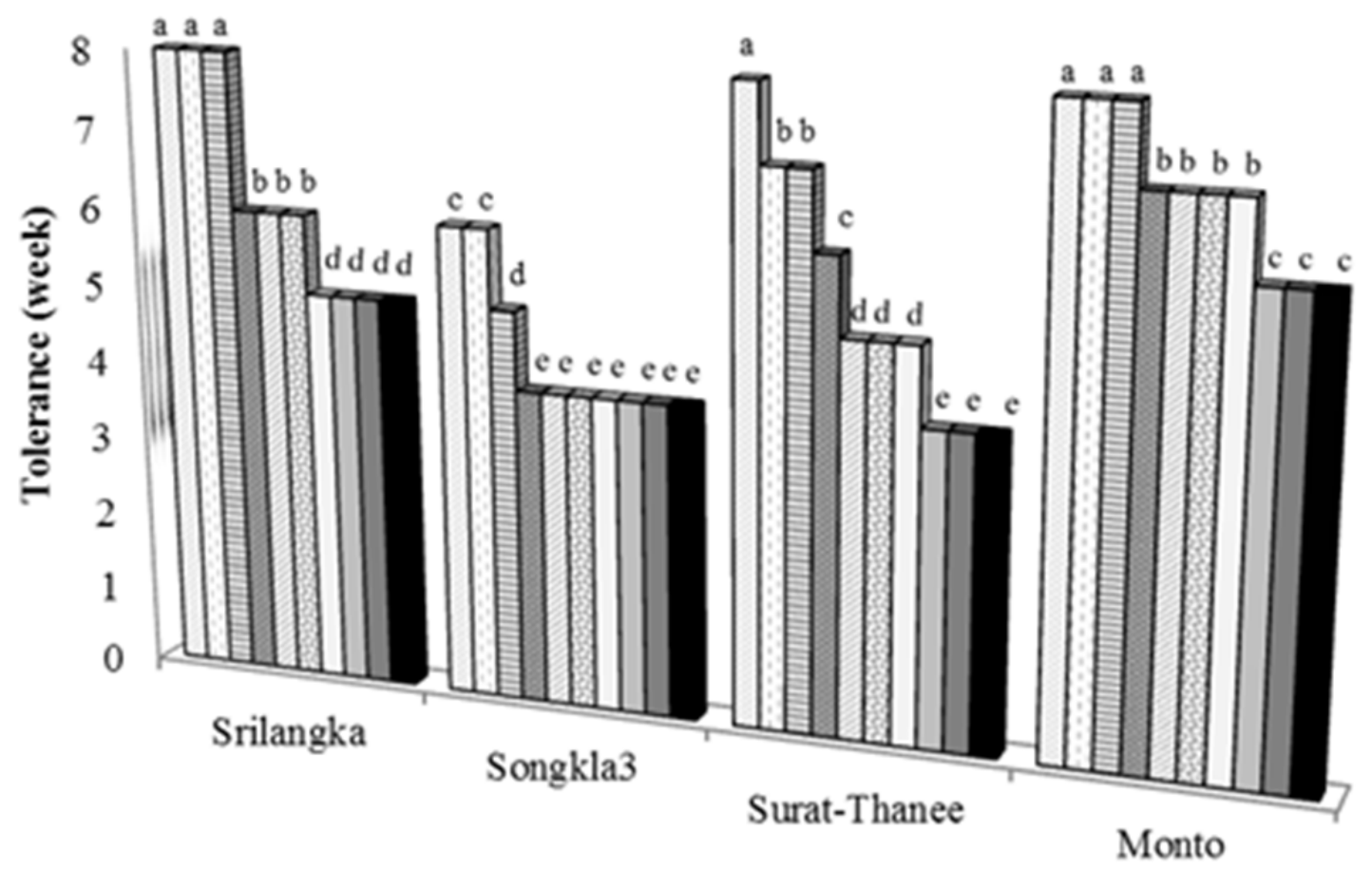

Figure 1. The tolerance of vetiver grass to $\mathrm{CN}$--contaminated water at each $\mathrm{CN}$--concentration level after treatment by four different vetiver grass ecotypes (bars associated with a common letter are not significantly different at 0.05 )

\subsection{Purification of CNContaminated Water}

Table 2 shows that from the $5 \mathrm{mg} \mathrm{CN} / \mathrm{L}$ contaminated water samples the removal of $\mathrm{CN}^{-}$was $100 \%$ after two weeks growth. $95 \%$ of the $10-30 \mathrm{mg} \mathrm{CN}^{-1} \mathrm{~L}$ contaminated water samples showed $100 \% \mathrm{CN}^{-}$removal after three weeks growth. At concentrations of $35-50 \mathrm{mg} \mathrm{CN}^{-} / \mathrm{L}, 30 \%$ of the vetiver grass plants were dead before all of the $\mathrm{CN}^{-}$was removed. The Monto ecotype removed $100 \%$ of the $\mathrm{CN}^{-}$from the $40-45 \mathrm{mg} \mathrm{CN}^{-} / \mathrm{L}$ samples after five weeks growth, while the other ecotypes were dead. All vetiver grass ecotypes were dead after 4-6 weeks growth and could not remove all the $\mathrm{CN}^{-}$from the water contaminated with $50 \mathrm{mg} \mathrm{CN}^{-} / \mathrm{L}$. Roongtanakiat el al. (2007) suggested that a toxicity treatment process depended on the tolerance of the plant species used. Selection of a plant with a higher toxic resistance for water treatment results in higher removal efficiency. However, Truong (2008) showed that vetiver grass was resistant to various heavy metal-contaminated soil and it grew in the presence of arsenic, cadmium, copper, chromium and zinc in ranges of 21-72, 45-48, 13-15, 5-18 and $\geq 880$ $\mathrm{mg} / \mathrm{Kg}$, respectively depended on ecotype.

The removal percentage of $\mathrm{CN}^{-}$from the $\mathrm{CN}^{-}$-contaminated water samples was $65.2-100 \%$ after the vetiver grass treatment (Table 3). Under $\mathrm{CN}^{-}$concentrations of 5, 10, 15, 2025 and $30 \mathrm{mg} / \mathrm{L}$, the vetiver grass ecotypes showed no significant difference in treatment efficiency $(\mathrm{p} \leq 0.5) ; \mathrm{CN}^{-}$was not detected in the water samples after treatment (Figure 2). In the $\geq 35 \mathrm{mg} \mathrm{CN}^{-} / \mathrm{L}$ samples, the results showed that the highest concentration of remaining $\mathrm{CN}^{-}$in the water after treatment was when the Surat-Thani ecotype was used at every $\mathrm{CN}^{-}$ concentration level, followed by Songkhlar3, Sri Lanka and Monto, respectively. The Monto ecotype was the most efficient ecotype at every $\mathrm{CN}^{-}$concentration level, although it did not show the best growth of leaves or roots. The Monto ecotype also had the highest tolerance to $\mathrm{CN}^{-}$at the 0.05 significance level. 
Table 2. Comparison of the remaining cyanide concentrations in water after treatment

\begin{tabular}{|c|c|c|c|c|c|c|c|c|}
\hline Growth time (week) & 1 & 2 & 3 & 4 & 5 & 6 & 7 & 8 \\
\hline \multicolumn{9}{|l|}{$5 \mathrm{mg} / \mathrm{L}$} \\
\hline Sri Lanka & $3.5 \pm 0.8$ & $0.2 \pm 0.1$ & ND & ND & ND & ND & ND & ND \\
\hline Songkhlar3 & $3.6 \pm 0.4$ & $0.3 \pm 0.1$ & ND & ND & ND & ND & - & - \\
\hline Surat-Thani & $3.5 \pm 1.9$ & $0.2 \pm 0.0$ & ND & ND & ND & ND & $\mathrm{ND}$ & ND \\
\hline Monto & $3.5 \pm 0.6$ & $0.2 \pm 0.1$ & $\mathrm{ND}$ & ND & ND & ND & ND & ND \\
\hline \multicolumn{9}{|l|}{$10 \mathrm{mg} / \mathrm{L}$} \\
\hline Sri Lanka & $12.5 \pm 0.6$ & $7.6 \pm 0.5$ & $1.9 \pm 0.2$ & ND & ND & ND & $\mathrm{ND}$ & ND \\
\hline Songkhlar3 & $11.1 \pm 1.3$ & $4.9 \pm 0.4$ & $1.8 \pm 0.4$ & ND & ND & - & - & - \\
\hline Surat-Thani & $10.4 \pm 1.6$ & $5.6 \pm 0.9$ & $2.0 \pm 0.7$ & ND & ND & ND & $\mathrm{ND}$ & - \\
\hline Monto & $10.6 \pm 0.9$ & $5.7 \pm 0.7$ & $1.8 \pm 0.4$ & ND & $\mathrm{ND}$ & ND & $\mathrm{ND}$ & $\mathrm{ND}$ \\
\hline \multicolumn{9}{|l|}{$15 \mathrm{mg} / \mathrm{L}$} \\
\hline Sri Lanka & $12.5 \pm 0.6$ & $7.6 \pm 0.5$ & $1.9 \pm 0.2$ & ND & ND & ND & $\mathrm{ND}$ & ND \\
\hline Songkhlar3 & $11.2 \pm 1.3$ & $4.9 \pm 0.4$ & $1.8 \pm 0.4$ & ND & ND & - & - & - \\
\hline Surat-Thani & $10.4 \pm 1.6$ & $5.6 \pm 0.9$ & $2.0 \pm 0.7$ & ND & ND & ND & $\mathrm{ND}$ & - \\
\hline Monto & $10.6 \pm 0.9$ & $5.7 \pm 0.7$ & $1.8 \pm 0.4$ & ND & ND & ND & $\mathrm{ND}$ & ND \\
\hline \multicolumn{9}{|l|}{$20 \mathrm{mg} / \mathrm{L}$} \\
\hline Sri Lanka & $12.5 \pm 0.6$ & $7.6 \pm 0.5$ & $1.9 \pm 0.2$ & ND & ND & ND & $\mathrm{ND}$ & ND \\
\hline Songkhlar3 & $11.1 \pm 1.3$ & $4.9 \pm 0.4$ & $1.8 \pm 0.4$ & ND & ND & - & - & - \\
\hline Surat-Thani & $10.4 \pm 1.6$ & $5.6 \pm 0.9$ & $2.0 \pm 0.7$ & ND & ND & ND & ND & - \\
\hline Monto & $10.6 \pm 0.9$ & $5.7 \pm 0.7$ & $1.8 \pm 0.4$ & ND & $\mathrm{ND}$ & ND & $\mathrm{ND}$ & ND \\
\hline \multicolumn{9}{|l|}{$25 \mathrm{mg} / \mathrm{L}$} \\
\hline Sri Lanka & $19.9 \pm 1.5$ & $4.7 \pm 0.8$ & $1.4 \pm 0.3$ & ND & ND & ND & - & - \\
\hline Songkhlar3 & $19.5 \pm 0.3$ & $9.9 \pm 0.4$ & $3.2 \pm 1.4$ & ND & - & - & - & - \\
\hline Surat-Thani & $20.2 \pm 0.6$ & $13.7 \pm 1.0$ & $5.3 \pm 0.5$ & ND & ND & - & - & - \\
\hline Monto & $20.1 \pm 0.2$ & $9.2 \pm 0.5$ & $3.3 \pm 0.7$ & ND & ND & ND & $\mathrm{ND}$ & - \\
\hline \multicolumn{9}{|l|}{$30 \mathrm{mg} / \mathrm{L}$} \\
\hline Sri Lanka & $21.9 \pm 0.2$ & $9.5 \pm 0.5$ & $4.0 \pm 0.6$ & $1.4 \pm 0.5$ & ND & ND & - & - \\
\hline Songkhlar3 & $21.7 \pm 1.5$ & $10.7 \pm 1.0$ & $4.2 \pm 0.8$ & ND & - & - & - & - \\
\hline Surat-Thani & $22.7 \pm 1.3$ & $10.7 \pm 1.2$ & $3.4 \pm 0.7$ & $0.9 \pm 0.3$ & ND & - & - & - \\
\hline Monto & $22.7 \pm 1.0$ & $11.8 \pm 0.7$ & $4.5 \pm 0.5$ & $1.8 \pm 0.6$ & ND & ND & $\mathrm{ND}$ & - \\
\hline \multicolumn{9}{|l|}{$35 \mathrm{mg} / \mathrm{L}$} \\
\hline Sri Lanka & $23.2 \pm 0.2$ & $16.4 \pm 1.3$ & $6.9 \pm 0.4$ & $1.5 \pm 0.4$ & ND & - & - & - \\
\hline Songkhlar3 & $28.8 \pm 2.2$ & $21.3 \pm 1.8$ & $14.5 \pm 0.1$ & $5.8 \pm 2.7$ & - & - & - & - \\
\hline Surat-Thani & $30.5 \pm 0.3$ & $21.7 \pm 1.4$ & $16.9 \pm 2.8$ & $7.2 \pm 2.1$ & $1.3 \pm 0.2$ & - & - & - \\
\hline Monto & $30.2 \pm 0.7$ & $21.1 \pm 1.2$ & $8.8 \pm 1.4$ & $4.2 \pm 1.2$ & $1.3 \pm 0.8$ & ND & ND & - \\
\hline \multicolumn{9}{|l|}{$40 \mathrm{mg} / \mathrm{L}$} \\
\hline Sri Lanka & $31.1 \pm 0.1$ & $25.9 \pm 0.3$ & $17.3 \pm 0.8$ & $7.6 \pm 0.2$ & $2.7 \pm 1.3$ & - & - & - \\
\hline Songkhlar3 & $35.4 \pm 1.6$ & $29.7 \pm 0.8$ & $19.9 \pm 1.2$ & $9.2 \pm 0.3$ & - & - & - & - \\
\hline Surat-Thani & $35.6 \pm 1.2$ & $26.5 \pm 0.5$ & $19.5 \pm 1.0$ & $11.5 \pm 1.5$ & - & - & - & - \\
\hline Monto & $35.7 \pm 1.4$ & $27.3 \pm 0.7$ & $19.9 \pm 1.0$ & $8.0 \pm 0.6$ & $3.1 \pm 1.1$ & ND & - & - \\
\hline \multicolumn{9}{|l|}{$45 \mathrm{mg} / \mathrm{L}$} \\
\hline Sri Lanka & $39.2 \pm 1.2$ & $29.8 \pm 1.2$ & $20.6 \pm 1.0$ & $10.9 \pm 0.2$ & $3.1 \pm 0.4$ & - & - & - \\
\hline Songkhlar3 & $40.3 \pm 0.9$ & $31.2 \pm 1.6$ & $23.8 \pm 1.3$ & $11.1 \pm 0.7$ & - & - & - & - \\
\hline Surat-Thani & $39.8 \pm 1.5$ & $31.5 \pm 1.2$ & $21.2 \pm 1.5$ & $12.8 \pm 1.4$ & - & - & - & - \\
\hline Monto & $40.1 \pm 0.8$ & $28.4 \pm 1.1$ & $19.6 \pm 0.9$ & $8.1 \pm 0.9$ & $3.6 \pm 1.2$ & ND & - & - \\
\hline \multicolumn{9}{|l|}{$50 \mathrm{mg} / \mathrm{L}$} \\
\hline Sri Lanka & $42.8 \pm 0.9$ & $36.5 \pm 0.6$ & $29.3 \pm 0.9$ & $21.3 \pm 0.5$ & $9.9 \pm 0.2$ & - & - & - \\
\hline Songkhlar3 & $44.2 \pm 0.3$ & $36.7 \pm 1.5$ & $27.5 \pm 0.7$ & $14.3 \pm 0.4$ & - & - & - & - \\
\hline Surat-Thani & $43.3 \pm 0.7$ & $29.5 \pm 1.4$ & $23.9 \pm 0.8$ & $17.8 \pm 0.8$ & - & - & - & - \\
\hline Monto & $42.0 \pm 0.8$ & $28.4 \pm 0.7$ & $21.2 \pm 0.2$ & $12.4 \pm 0.8$ & $7.8 \pm 1.1$ & $3.3 \pm 0.5$ & - & - \\
\hline
\end{tabular}

Note. ND is non-detected. 
Table 3. The remaining $\mathrm{CN}^{-}$-concentrations in water after treatment and the tolerance of vetiver grass.

\begin{tabular}{|c|c|c|c|c|c|c|c|c|c|c|c|c|}
\hline \multirow{2}{*}{$\begin{array}{c}\mathrm{CN}^{-} \\
\text {)mg/l) }\end{array}$} & \multicolumn{4}{|c|}{$\mathrm{CN}^{-}$conc. in water) $\left.\mathrm{mg} / \mathrm{l}\right)$} & \multicolumn{4}{|c|}{$\%$ removal efficiency } & \multicolumn{4}{|c|}{ Tolerance (week) } \\
\hline & Sri. & Song. & Surat. & Mon. & Sri. & Song. & Surat. & Mon. & Sri. & Song. & Surat. & Mon. \\
\hline 5 & $\mathrm{NDa}$ & $\mathrm{NDa}$ & $\mathrm{NDa}$ & $\mathrm{NDa}$ & $100 \mathrm{a}$ & $100 \mathrm{a}$ & $100 \mathrm{a}$ & $100 \mathrm{a}$ & $8 \mathrm{a}$ & $6 c$ & $8 \mathrm{a}$ & $8 \mathrm{a}$ \\
\hline 10 & $\mathrm{NDa}$ & $\mathrm{NDa}$ & $\mathrm{NDa}$ & $\mathrm{NDa}$ & $100 \mathrm{a}$ & $100 \mathrm{a}$ & $100 \mathrm{a}$ & $100 \mathrm{a}$ & $8 \mathrm{a}$ & $6 \mathrm{c}$ & $7 b$ & $8 \mathrm{a}$ \\
\hline 15 & $\mathrm{NDa}$ & $\mathrm{NDa}$ & $\mathrm{NDa}$ & $\mathrm{NDa}$ & $100 \mathrm{a}$ & $100 \mathrm{a}$ & $100 \mathrm{a}$ & $100 \mathrm{a}$ & $8 \mathrm{a}$ & $5 d$ & $7 b$ & $8 \mathrm{a}$ \\
\hline 20 & $\mathrm{NDa}$ & $\mathrm{NDa}$ & $\mathrm{NDa}$ & $\mathrm{NDa}$ & $100 \mathrm{a}$ & $100 \mathrm{a}$ & $100 \mathrm{a}$ & $100 \mathrm{a}$ & $6 b$ & $4 \mathrm{e}$ & $6 \mathrm{c}$ & $7 b$ \\
\hline 25 & $\mathrm{NDa}$ & $\mathrm{NDa}$ & $\mathrm{NDa}$ & $\mathrm{NDa}$ & $100 \mathrm{a}$ & $100 \mathrm{a}$ & $100 \mathrm{a}$ & $100 \mathrm{a}$ & $6 b$ & $4 \mathrm{e}$ & $5 \mathrm{~d}$ & $7 b$ \\
\hline 30 & $\mathrm{NDa}$ & $\mathrm{NDa}$ & $\mathrm{NDa}$ & $\mathrm{NDa}$ & $100 \mathrm{a}$ & $100 \mathrm{a}$ & $100 \mathrm{a}$ & $100 \mathrm{a}$ & $6 b$ & $4 e$ & $5 d$ & $7 b$ \\
\hline 35 & $\mathrm{NDa}$ & $5.8 \mathrm{f}$ & $1.3 \mathrm{c}$ & $\mathrm{NDa}$ & $100 \mathrm{a}$ & $83.5 \mathrm{c}$ & $96.4 \mathrm{~b}$ & $100 \mathrm{a}$ & $5 \mathrm{~d}$ & $4 \mathrm{e}$ & $5 d$ & $7 b$ \\
\hline 40 & $2.7 \mathrm{~d}$ & $9.2 \mathrm{~g}$ & $11.5 \mathrm{~h}$ & $\mathrm{NDa}$ & $93.4 \mathrm{~b}$ & $76.9 \mathrm{~d}$ & $71.4 \mathrm{~d}$ & $100 \mathrm{a}$ & $5 \mathrm{~d}$ & $4 e$ & $4 \mathrm{e}$ & $6 c$ \\
\hline 45 & $3.1 \mathrm{e}$ & $11.1 \mathrm{~h}$ & $12.8 \mathrm{i}$ & $\mathrm{NDa}$ & $93.1 \mathrm{~b}$ & $75.2 \mathrm{~d}$ & $76.9 \mathrm{~d}$ & $100 \mathrm{a}$ & $5 d$ & $4 \mathrm{e}$ & $4 e$ & $6 c$ \\
\hline 50 & $9.9 \mathrm{~g}$ & $14.3 \mathrm{j}$ & $17.4 \mathrm{k}$ & $3.3 \mathrm{e}$ & $80.3 c$ & $71.4 \mathrm{~d}$ & $65.2 \mathrm{e}$ & $93.4 \mathrm{~b}$ & $5 \mathrm{~d}$ & $4 \mathrm{e}$ & $4 \mathrm{e}$ & $6 c$ \\
\hline
\end{tabular}

Note. ND is non-detected; small letters stand for significance at 0.05 levels.

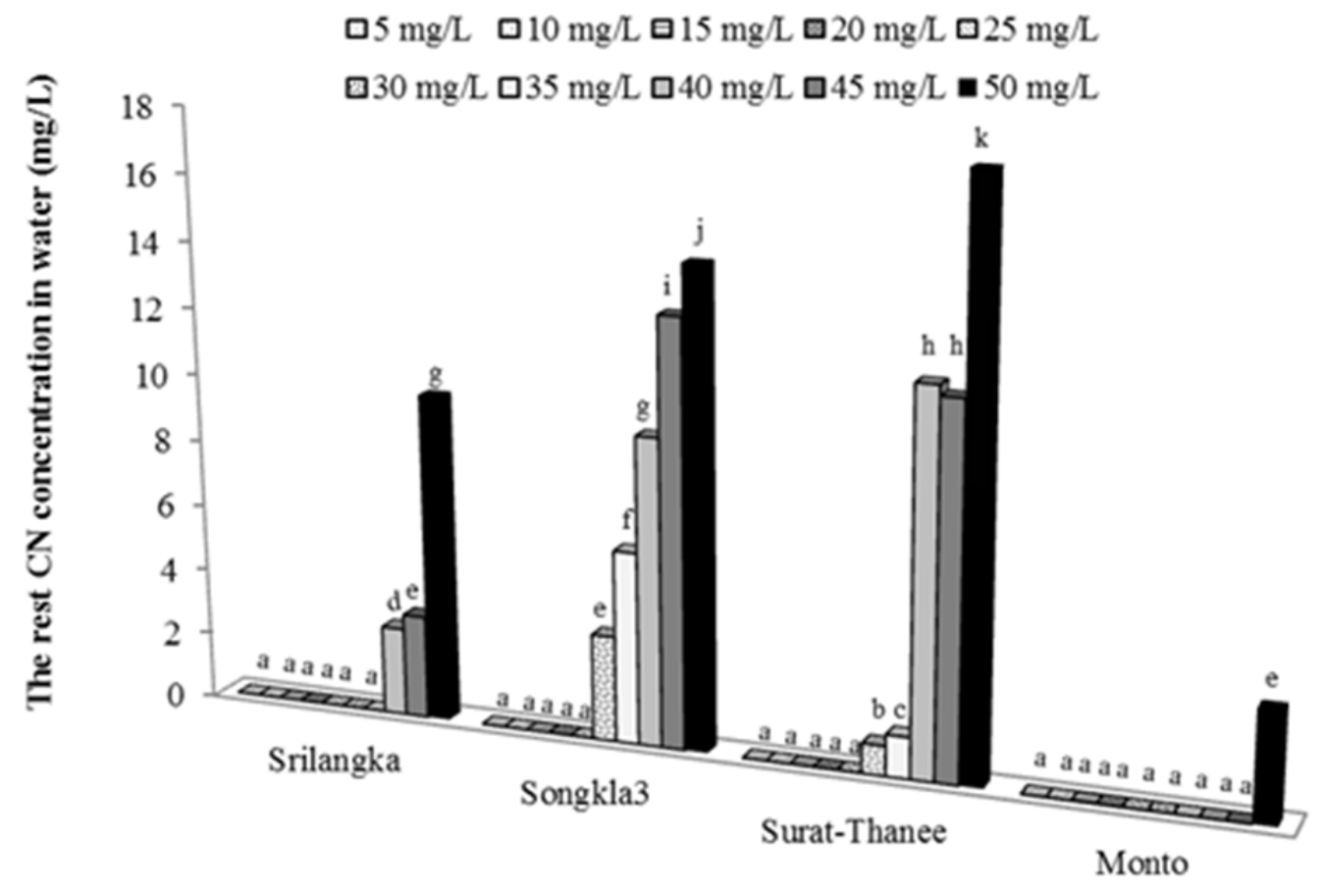

Figure 2. The remaining $\mathrm{CN}^{-}$in the contaminated water at each $\mathrm{CN}^{-}$concentration level after treatment by four different vetiver grass ecotypes (Bbars associated with a common letter are not significantly different at 0.05 )

\subsection{The Effective Factors for CN Contaminated Water Treatment}

The relationship between the amount of $\mathrm{CN}^{-}$adsorption in $5-50 \mathrm{mg} \mathrm{CN}^{-} / \mathrm{L}$ contaminated water and tolerance by week survival was linear, with correlations between 0.79-0.97 (Figure 3). The results showed that the $\mathrm{CN}^{-}$ adsorption had a high correlation with vetiver grass tolerance. This indicated that the tolerance of vetiver grass (number of weeks of survival) had affected $\mathrm{CN}^{-}$adsorption. In other words, the vetiver grass ecotype which had the longest survival period after treatment would have a longer time to uptake $\mathrm{CN}^{-}$from the water, resulting in higher levels of $\mathrm{CN}^{-}$removal. The relationship between $\mathrm{CN}^{-}$adsorption and vetiver grass growth (leaf and root 
lengths) as also showed relatively high correlations: 0.68 and 0.72 respectively (Figure 4 ). The correlations could indicate that tolerance is the most important factor when selecting a vetiver grass ecotype for $\mathrm{CN}^{-}$contaminated water treatment, followed by leaf and root lengths, respectively, as these could be representative of the vetiver grass's biomass. Truong, Foong, Guthrie \& Hung (2010) investigated the degradation of residue from a shale oil waste dump using Vetiveria zizanioides, Paspalum notatum, Stemotaphrum secundatum and Pennisetum glaucum. The results from this experiment indicated that vetiver grass had the highest survival rate (up to $98.6 \%$ ), coverage and biomass, and was considered the best species for vegetation rehabilitation. Taechapinyawat (2005) showed that root length was not the principal factor in wastewater treatment. The vetiver grass could easily uptake nutrients or toxic substances in wastewater without elongating its roots for nutrient uptake. Kadlec and Knight (1996) suggested that vetiver grass had a great capability to absorb and decrease toxic substances in the environment as it accumulates more toxic substances in the roots than the leaves. Naser et al. (2013) showed that vetiver grass not only has a high resistance to high concentrations of heavy metals, but also accumulated these heavy metals in roots and leaves at high concentrations. Most of heavy metals were accumulated in the roots rather than the leaves. Therefore, it may be possible that $\mathrm{CN}^{-}$accumulated in the roots halts the growth of vetiver grass roots, as possibly shown by the above results where root growth rate was lower relative to leaf growth rate. There were significant differences in root lengths between the vetiver grass grown in $\mathrm{CN}^{-}$-contaminated water and control 1 and 2.

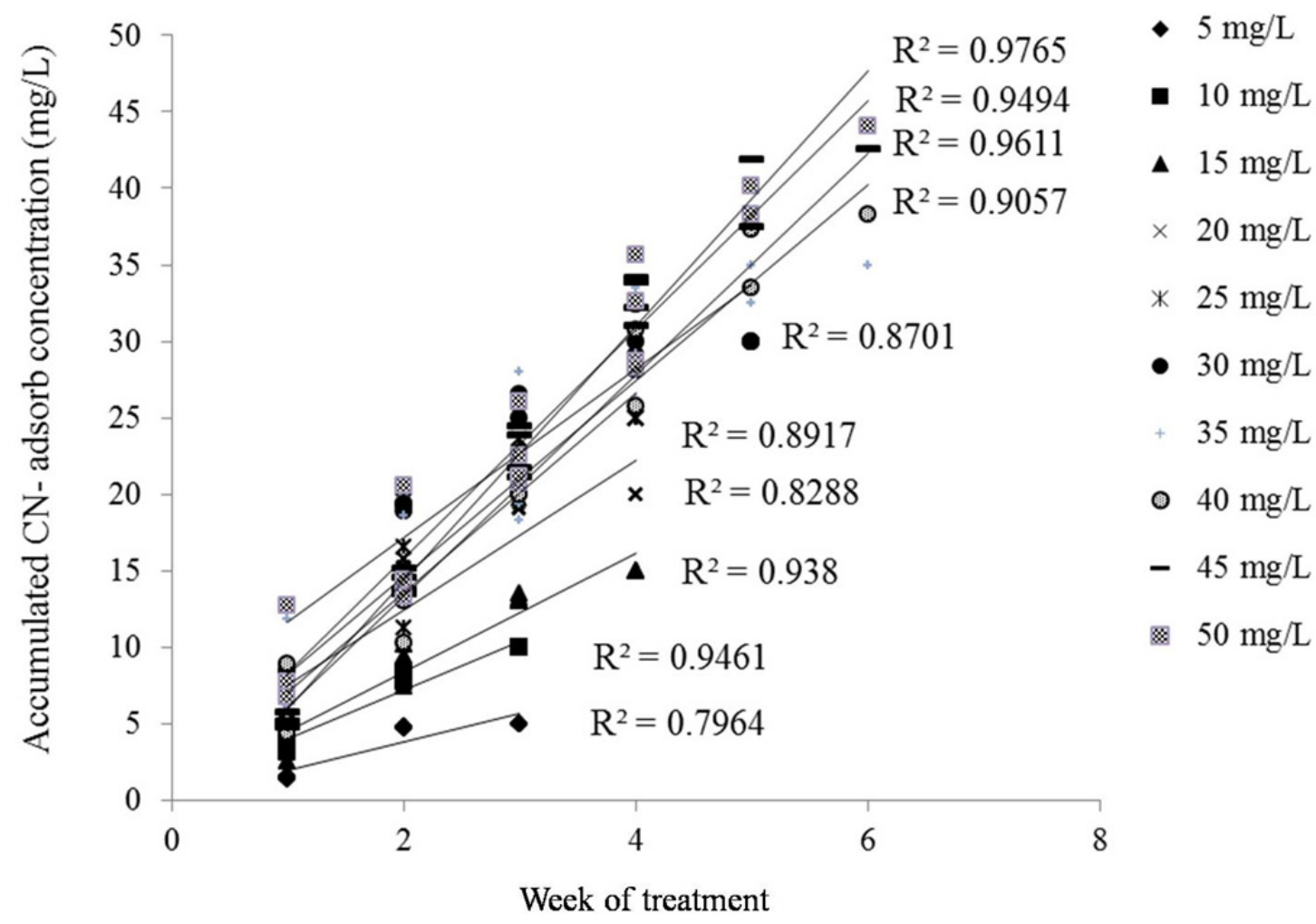

Figure 3. The correlation between accumulated $\mathrm{CN}^{-}$adsorption and time of $\mathrm{CN}^{-}$-contaminated water treatment by vetiver grass 


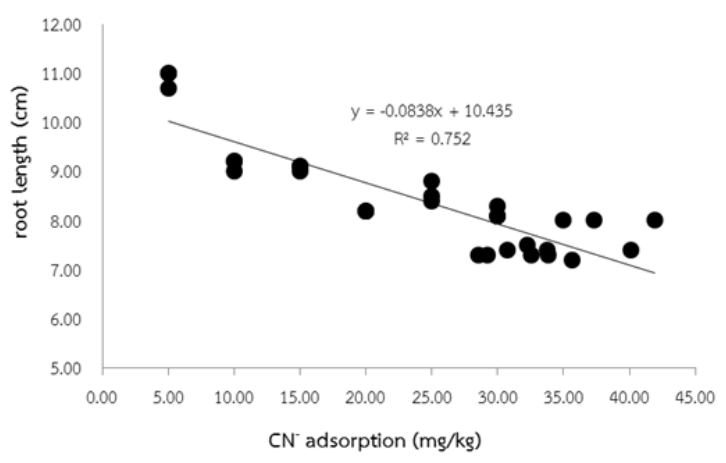

(a)

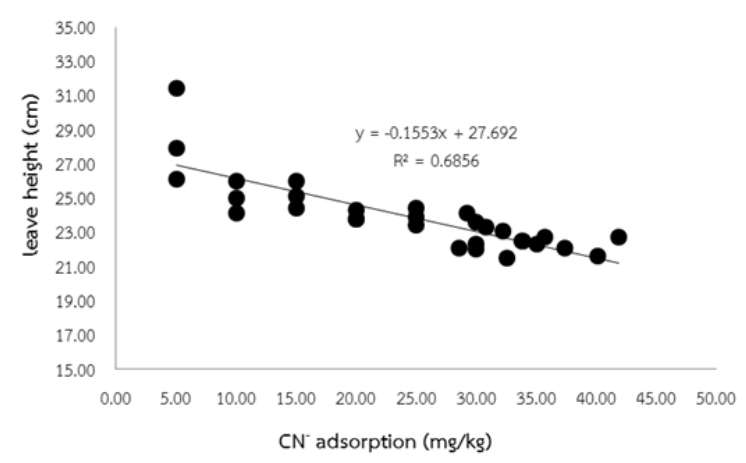

(b)

Figure 4. The correlation between (a) $\mathrm{CN}^{-}$adsorption and leaf length, (b) $\mathrm{CN}^{-}$adsorption and root length after treatment by all vetiver grass ecotypes

\section{Conclusion}

The results presented above demonstrate that the vetiver grass is very efficient at treating $\mathrm{CN}^{-}$-contaminated water. All vetiver grass ecotypes grew and had a 100\% survival rate for one month. The Songkhlar3 ecotype had the longest leaves, followed by Surat-Thani, Sri Lanka and Monto, respectively. However, there were no statistical differences $(\mathrm{p} \leq 0.05)$ between leaf lengths among the three ecotypes, Surat-Thani, Sri Lanka and Monto, in water contaminated with $\geq 20 \mathrm{mg} \mathrm{CN}^{-} / \mathrm{L}$. There was no statistical differences $(\mathrm{p} \leq 0.05)$ between the root lengths of all ecotypes. The $\mathrm{CN}^{-}$removal efficiency of vetiver grass is high over short timescales under lower $\mathrm{CN}^{-}$concentrations in water: only 2-3 weeks for $5-25 \mathrm{mg} \mathrm{CN}^{-} / \mathrm{L}$ treatments. All vetiver grass ecotypes could purify $\mathrm{CN}^{-}$-contaminated water at lower concentrations, especially $\leq 35 \mathrm{mg} \mathrm{CN}^{-} / \mathrm{L}$. However, the Songkhlar3, Sri Lanka, Surat-Thani ecotypes were dead before the purification of $\mathrm{CN}^{-}$in water at $\geq 40 \mathrm{mg} \mathrm{CN}^{-} / \mathrm{L}$ was complete. This was thought to be due to $\mathrm{CN}^{-}$reaching a toxic level for the plants, which only survived for 4-5 weeks. The Monto ecotype is considered the most suitable ecotype for $\mathrm{CN}^{-}$phytoremediation, followed by Sri Lanka, Songkhlar3 and Surat-Thani. The Monto ecotype tolerated $\mathrm{CN}^{-}$better than the others, showing $100 \%$ $\mathrm{CN}^{-}$removal, the recommended maximum level of contamination being $45 \mathrm{mg} \mathrm{CN}^{-} / \mathrm{L}$. All vetiver grass ecotypes can be killed with $\mathrm{CN}^{-}$-contaminated water up to $50 \mathrm{mg} \mathrm{CN}^{-} / \mathrm{L}$ in $4-5$ weeks. The results indicated that the tolerance of vetiver grass was a more important factor when selecting a vetiver grass ecotype for $\mathrm{CN}^{-}$ phytoremediation than growth rate.

The results represent a useful dataset that is applicable to real problems. Several improvement procedures, such as detailed studies of $\mathrm{CN}^{-}$accumulation in different parts of the plants, need to be conducted to indicate the suitability of such plants to absorb $\mathrm{CN}^{-}$from contaminated water. Measurements such as the number of leaves and roots, residual biomass and $\mathrm{CN}^{-}$accumulation in leaves and roots would also be valuable.

\section{Acknowledgments}

Authors would sincerely like to acknowledge Pibulsongkarm Rajabhat University under the aid of National Research Council of Thailand for financial support. The Faculty of Science and technology, Pibulsongkarm Rajabhat University for measurement laboratory is gratefully acknowledged.

\section{References}

Akcil, A. G., Karahan, H., \& Ciftci, O. S. (2003). Biological treatment of cyanide by natural isolated bacteria $\begin{array}{lllll}\text { (Pseudomonas } & \text { sp.). } & \text { Minerals } & \text { Engineering, } & \text { 16(7), }\end{array}$ http://dx.doi.org/10.1016/S0892-6875(03)00101-8

Alkorta, I., \& Garbisu, C. (2001). Phytoremediation of organic contaminants in soils. Bioresource Technology, 79(3), 273-276. http://dx.doi.org/10.1016/S0960-8524(01)00016-5

Andra, S. S, Datta, R., Sarkar, D., Saminathan, S. K. M., Mullens, C. P., \& Bach, S. B. H. (2009). Analysis of phytochelatin complexes in the lead tolerant vetiver grass [Vetiveria zizanioides (L.)] using liquid chromatography and mass spectrometry. Environmental Pollution, 157(7), 2173-2183. http://dx.doi.org/ 10.1016/j.envpol.2009.02.014

Botz, M. M., Mudder, T. I., \& Akcil, A. U. (2005). Cyanide treatment: Physical, chemical and biological 
processes. Developments in Mineral Processing $\quad$ 15(1), http://dx.doi.org/10.1016/S0167-4528(05)15028-5.

Dash, R. R., Gaur, A., \& Balomajumder, C. (2009). Cyanide in industrial wastewater and its removal: A review on biotreatment. Journal of Hazard Materials, $163(1), \quad 1$. http://dx.doi.org/10.1016/j.jhazmat.2008.06.051

Dudai, N., \& Putievsky, E. (2006). Growth management of vetiver (Vetiveria zizanioides) under Mediterranean conditions. Journal of Environmental Management, 81(1), 63-71.

Dulton, P. A., Smith, R. J., \& Truong, P. N. V. (1996). Vetiver grass hedges for erosion control on cropped flood plain: Hedge hydraulics. Agricultural Water Management, 31(1-2), 91-104. http://dx.doi.org/ 10.1016/0378-3774(95)01230-3

Eisler, R., \& Wiemeyer, S. N. (2004). Cyanide hazards to plants and animals from gold mining and related water issues. Reviews of Environmental Contamination and Toxicology, 183, 21-54.

Elbel, M., Evangelou, M. W. H., \& Schaeffer, A. (2007). Cyanide phytoremediation by water hyacinths $\begin{array}{llll}\text { (Eichhornia } \quad \text { Crassipes). } & \text { 66(5), }\end{array}$ http://dx.doi.org/10.1016/j.chemosphere.2006.06.041

El-Gendy, A. S., Biswas, N., \& Bewtra, J. K. (2004). Growth of water hyacinth in municipal landfill leachate with different pH. Environmental Technology, 25(7), 833-840.

Gupta P., Roy, S., \& Mahindrakar, A. B. (2012). Treatment of water using water hyacinth, water lettuce and vetiver grass - A Review. Resources and Environment, 2(5), 202-215. http://dx.doi.org/10.5923/j.re.20120205.04

Kadlec, R. H., \& Knight, R. L. (1996). Treatment Wetlands, USA, FL: CRC Press, Lewis Publishers.

Logsdon, M. J., Hagelstein, K., \& Mudder, T. I. (1999). The management of cyanide in gold extraction (1st ed.) Canada: International Council on Metals and the Environment.

Lu, Q. (2009). Evaluation of aquatic plants for phytoremediation of eutrophic storm waters. Ph.D Thesis, University of Florida, Florida.

Maegala, N. M., Fridelina, S., \& Abdul, L. I. (2011). Bioremediation of cyanide by optimized resting cells of rhodococcus strains isolated from Peninsular Malaysia. International Journal of Bioscience, Biochemistry and Bioinformatics, 1(2), 98-101.

Naser, A. A., Maria, E. P., Iqbal, A., Armando, C. D., Shahid, U., \& Nafees, A. K. (2013). Phytotechnology: remediation of environmental contaminant. USA: CRC Press.

Newman, L. A., \& Reynolds, C. (2004). Phytodegradation of organic compounds. Current Opinion in Biotechnology, 15(3), 225-30. http://dx.doi.org/10.1016/j.copbio.2004.04.006

Pang, J., Chan, G. S. Y., Liang, J., \& Wong, M. H. (2003). Physiological aspects of vetiver grass for rehabilitation in abandoned metalliferous mine wastes. Chemosphere, 52(9), 1559-1570. http://dx.doi.org/ 10.1016/S0045-6535(03)00496-X

Patil, Y. B., \& Paknikar, K. M. (2000). Development of a process biodetoxification of metal cyanides from wastewaters. Process Biochemistry, 35(10), 1139-1151. http://dx.doi.org/10.1016/S0032-9592(00)00150-3

Roongtanakiat, N. (2009). Vetiver phytoremediation for heavy metal decontamination. Pacific Rim Vetiver Network Techical Bullatin, 1, 1-20.

Roongtanakiat, N., Tangruangkiat, S., \& Meesat, R. (2007). Utilization of vetiver grass (Vetiveria zizanioides) for removal of heavy metals from industrial wastewater. ScienceAsia, 33, 397-403. http://dx.doi.org/ 10.2306/scienceasia1513-1874.2007.33.397

Santos, B. A. Q., Ntwampe, S. K. O., \& Doughari, J. H. D. (2013). Continuous biotechnological treatment of cyanide contaminated waters by using a cyanide resistant species of Aspergillus awamori. Environmental Biotechnology-New Approaches and Prospective Applications. Croatia: Intech. pp. 123-146. http://dx.doi.org/10.5772/53349

Sheldon, A., \& Menzies, N. W. (2005). The effect of copper toxicity on the growth and root morphology of Rhodes grass (Chloris gayana Knuth.) in resin buffered solution culture. Plant and Soil, 278(1-2), 341-349. http://dx.doi.org/10.1007/s11104-005-8815-3

Somwang, T., Yothasiri, A., Tubngearn, S., Panichnork, K., \& Limarroon, S. (2005). Growth of different in 
vetiver ecotypes as affected by waste water from industrial plants. Proceeding of 43st National Conference of Kasetsart University, Bangkok. Thailand. pp. 549-557.

Taechapinyawat, S. (2005). Efficiency of using vetiver for industrial tapioca starch wastewater treatment. Proceedings of 43rd Kasetsart University Annual Conference: Plants. Bangkok. Thailand. pp. 641-649.

The Nation. (2013). Loei 'could yield 1 million tonnes of gold'. Retrived February 22, 2014, from http://www.nationmultimedia.com/business/Loei-could-yield-1-million-tonnes-of-gold-30203100.html

The National Health Commission office. (2011). Health impact from gold mining in Loei province disclosed. Retrived February 22, 2014, from http://en.nationalhealth.or.th/node/186

Trapp, S., Larsen, M., Pirandello, A., \& Danquah-Boakye, J. (2003). Feasibility of cyanide elimination using plants. The European Journal of Mineral Processing and Environmental Protection, 3(1), 128-137.

Truong, P. (2008). Research and development of the vetiver system for treatment of polluted water and contaminated land. 1st Workshop Proceedings. India. pp. 60-71.

Truong, P., Carlin, G., Cook, F., \& Thomas, E. (2003). Vetiver grass hedges for water quality improvement in acid sulfate soils, Queensland, Australia. Proceeding of the 3rd International Conference on Vetiver and Exhibition, Guangzhou, China, 194-205.

Truong, P. N. V., Foong, Y. K., Guthrie, M., \& Hung, Y. T. (2010). Phytoremediation of heavy metal contaminated soils and water using vetiver grass. Environmental Bioengineering, 11, $233-275$. http://dx.doi.org/ 10.1007/978-1-60327-031-1_8

Truong, P., Van, T. T., \& Pinners, E. (2015). The vetiver system: vetiver grass-the plant. Retrived September 3, 2015, from http://www.vetiver.org/TVN-Handbook\%20series/TVN-series 11 -vetiver\%20plant.htm

UNEP/OCHA. (2000). Assessment Mission-Cyanide spill at Baia Mare. Report, United Nations Environment Programme/Office for the Coordination of Humanitarian Affairs, UNEP Regional Office Europe, Geneva, $\begin{array}{lllll}\text { Switzerland. } & \text { Retrived } & \text { February } & \text { 22, } & \text { from }\end{array}$ http:/www.reliefweb.int/ocha_ol/programs/response/unep/rombaiamare.html

Watcharapon, W., \& Suntaree, S. (2009). Negative impacts of phuthapfa gold mine, Loei Province, and people's opposition. Mining and Women in Asia: Experiences of women protecting their communities and human rights against corporate mining. Asia Pacific, Forum on Women, Thailand: Law and Development (APWLD).

Xia, H. P., Liu, S. Z., \& Ao, H. X. (2000). A study on purification and uptake by vetiver grass of garbage leachate. Proceedings of the Second International Conference on Vetiver. Office of the Royal Development Projects Board, Bangkok, 394-406.

\section{Copyrights}

Copyright for this article is retained by the author(s), with first publication rights granted to the journal.

This is an open-access article distributed under the terms and conditions of the Creative Commons Attribution license (http://creativecommons.org/licenses/by/3.0/). 